CLINICAL STUDY

\title{
Screening for membrane hormone receptor expression in primary aldosteronism
}

\author{
O Zwermann, Y Suttmann, M Bidlingmaier, F Beuschlein and M Reincke \\ Medizinische Klinik Innenstadt, Ludwig-Maximilian University, Ziemssenstrasse 1, 80336 Munich, Germany \\ (Correspondence should be addressed to M Reincke; Email: martin.reincke@med.uni-muenchen.de)
}

\begin{abstract}
Objective: The investigation of expression and functional relevance of G-protein coupled receptors in primary aldosteronism (PA) by molecular and clinical studies.

Patients and methods: Tissues of 14 aldosterone-producing adenomas (APA), of one unilateral adrenal hyperplasia and of six healthy adult adrenal glands; 12 patients with confirmed PA due to APA; $(n=5)$, idiopathic hyperaldosteronism $(n=7)$ and 8 control subjects $(C)$. The tissues were subjected to a quantitative PCR for determination of mRNA expression levels of AT2R1, GIPR, MC2R, GnRHR, LHR, TRHR, TSHR, glucagon-R, V1aR, V2R, and 5-HT4R. The patients and controls were enrolled in a test protocol consisting of stimulation by posture, mixed meal, ACTH, GnRH, TRH, glucagon, vasopressin, and metoclopramide (MCP). Three patients could be analyzed by both studies. A positive response was defined as an aldosterone increase of more than $50 \%$ following stimulation.

Results: All the tissues revealed AT2R1, MC2R, AVPR, and 5-HT4R mRNA expression. LHR mRNA was found in normal adrenals and 13 adrenal tumors. By contrast with normal adrenals tumorous adrenal tissue expressed GnRHR mRNA (4/15) and TSHR mRNA (1/15). Both the patients and controls responded to posture, ACTH, glucagon, AVP, and MCP. Specific responses were seen in one patient following TRH and three patients following GnRH stimulation.

Conclusions: We provide evidence for peptide hormone responsiveness to various peptide hormones in patients with PA, including GnRH and TRH. A good correlation between clinical and molecular testing could be observed, making an involvement of the receptor expressed in PA possible.
\end{abstract}

European Journal of Endocrinology $160443-451$

\section{Introduction}

Primary aldosteronism (PA) is a frequent cause of secondary hypertension with more recent studies providing evidence for aldosterone excess in up to $10 \%$ of hypertensive patients $(1,2)$. Autonomous production of the mineralocorticoid aldosterone, which was first described in its classical form by Jerome Conn in 1955 (3), results in sodium retention and potassium depletion with hypertension and low potassium levels as well as concomitant organ damage. Besides the rare familial forms, including the glucocorticoid remediable aldosteronism (familial aldosteronism type 1, FHI) or familial aldosteronism type 2 , overt aldosterone secretion in the vast majority of cases is caused by idiopathic bilateral adrenal hyperplasia or non-familial forms of aldosterone-producing adrenal adenoma (APA).

In 1992, the exciting cases of food-dependent Cushing's syndrome have been attributed to adrenal expression of the gastrointestinal inhibitory peptide receptor (GIPR) (4, 5). Based on these and other clinical and molecular observations, the concept of hypercortisolism caused by peptide hormones other than ACTH has been further substantiated (see (6) for review). In the meantime, a variety of receptors have been identified in adrenal Cushing's syndrome due to ACTH-independent macronodular adrenal hyperplasia (AIMAH), cortisol-producing adenomas and incidentalomas with subclinical Cushing's syndrome (7-10). In patients with AIMAH in nearly all tissue samples, expression of at least one ectopic receptor could be demonstrated $(7,8)$. These ectopic receptors included those for $\operatorname{GIP}(4,5)$, LH/hCG (11-13), glucagon (9), $\beta$-adrenergic receptors $(7,14)$, and interleukin-1 (15). Furthermore, the overexpression of eutopic receptors could be linked to cortisol production in several cases. Specifically, receptors for angiotensin II (16), vasopressin (17-19), and serotonin $(20,21)$ could be shown to be involved in the pathogenesis of autonomous cortisol secretion.

The concept of the expression of aberrant peptide hormone receptors in cortisol overproduction has sparked interest for similar investigations in patients with PA. Several receptors have been shown to be expressed in aldosterone-producing adrenal tumors in vitro. These included receptors for LH (22), GnRH (23), and vasopressin (24). Moreover, aldosterone responses to 
serotoninergic substances via the 5-HT4 receptor have been reported in patients with PA and healthy volunteers (25-27).

However, a systematic study investigating multiple stimuli as part of a standardized test protocol including both patients and healthy volunteers is lacking. Therefore, this study was initiated to answer open questions related to functional significance of aberrant hormone responsiveness in PA.

\section{Patients and methods}

\section{Patients and tissues}

Expression studies Tissues from 14 patients with clinically and histopathologically confirmed APA and from one patient with unilateral adrenal hyperplasia were used for RealTime PCR analysis. The tissues were collected after written informed consent of the patients and after approval by the ethics committee of the Universities of Munich and Freiburg. As a reference six normal adrenal tissues were used. All the tissues were immediately snap frozen in liquid nitrogen after removal and stored at $-80{ }^{\circ} \mathrm{C}$.

Clinical studies Six patients with bilateral idiopathic hyperaldosteronism (IHA), one with unilateral adrenal hyperplasia, five patients with APA and eight control subjects were enrolled into the clinical part of the study following written informed consent. The study was approved by the ethics committee of the LudwigMaximilians University of Munich. All patients had newly diagnosed PA. Spironolactone was paused for at least 4 weeks and $\beta$-blockers were stopped at least 8 days prior to study entry. Hypokaliemia was corrected at least the day before the test protocol. Diagnosis of PA was established on the basis of a pathological aldosterone to renin ratio and an insufficient suppression of aldosterone following an i.v. sodium load using $2 \mathrm{l}$ of $0,9 \% \mathrm{NaCl}$ within $4 \mathrm{~h}$. The classification as APA or IHA was based on the results in the posture test, adrenal imaging by computer tomography (CT) or magnetic resonance imaging (MRI), selective adrenal vein sampling and on histopathological examination of the tissue after adrenalectomy, if performed. The patient with unilateral hyperplasia was operated because of suspected APA by imaging and adrenal vein sampling. Histopathological examination revealed adrenal hyperplasia without a macroadenoma. Following unilateral adrenalectomy, blood pressure and potassium levels completely normalized leading to the diagnosis of unilateral adrenal hyperplasia. The clinical characteristics of the patients are summarized in Table 1.

\section{Real-time quantitative PCR}

Total mRNA was extracted using the SV total RNA isolation kit (Promega). One microgram of RNA was transcribed by an MMLV reverse transcriptase (Promega) with oligo(dT)15- and random hexadeoxynucleotide primers (Promega) mixed 1:1 using the standard protocol provided by the manufacturer and a reaction temperature of $42{ }^{\circ} \mathrm{C}$ for $50 \mathrm{~min}$. The cDNA was diluted 1:10 and $2 \mu \mathrm{l}$ were subjected to PCR. Intron spanning primers were designed by the Universal Probe Library Assay Center (Roche) or the Jellyfish software (Labvelocity, San Francisco, CA, USA). Primer sequences are given in Table 2. AT2R1 primers were placed within the same exon in such a way that all transcript variants were amplified. A control without RT was included for each sample in that assay. A SYBRgreen based real-time PCR was performed using the $\mathrm{iQ}$ SYBR green supermix (BioRad) with $200 \mathrm{nM}$ of each primer on a Statagene Mx3000 instrument (Stratagene, La Jolla, CA, USA). Each PCR consisted of an initial denaturation at $95^{\circ} \mathrm{C}$ for $3 \mathrm{~min}, 40$ cycles consisting of $10 \mathrm{~s}$ at $95^{\circ} \mathrm{C}, 30 \mathrm{~s}$ at $60^{\circ} \mathrm{C}$ and $30 \mathrm{~s}$ at $72^{\circ}$ followed by a melting curve. For LHR, annealing temperature was $56{ }^{\circ} \mathrm{C}$. A standard curve for quantification was created with cDNA from human pituitary (TRHR, GnRHR), normal adrenals (AT2R1, MC2R, V1aR, V2R, 5-HT4, hPRT (human hypoxanthine phosphoribosyltransferase 1)) or a reference RNA mixture (Stratagene qPCR reference total RNA, human; GIPR, LHR, TSHR, GCGR). Data were evaluated by the MxPro (Statagene) and the Excel software (Microsoft). Results were normalized for

Table 1 Clinical characteristics of patients participating in both parts of the study ( \pm S.D.).

\begin{tabular}{lllll}
\hline & \multicolumn{3}{c}{ Clinical testing } & Expression studies \\
\cline { 2 - 4 } & APA & IHA & Controls & 15 \\
$N$ & 5 & 7 & 8 & $53 \pm 2.6$ \\
Age & $51 \pm 14.9$ & $60.6 \pm 7.0$ & $26 \pm 2.9$ & $174 \pm 11$ \\
Mean systolic blood pressure $(\mathrm{mmHg})$ & $151 \pm 19$ & $169 \pm 16$ & $113 \pm 14$ & $103 \pm 26$ \\
Mean diastolic blood pressure $(\mathrm{mmHg})$ & $100 \pm 10$ & $100 \pm 8$ & $80 \pm 11$ & $2.9 \pm 0.15$ \\
Lowest potassium level $(\mathrm{mmol} / \mathrm{l})$ & $2.8 \pm 0.6$ & $3.44 \pm 0.29$ & $3.9 \pm 0.25$ & 14 \\
Spontaneous hypokalemia $(n)$ & 5 & 5 & 0 & $102.5 \pm 26.0$ \\
Aldosterone/renin ratio $(\mathrm{ng} / \mathrm{mU})$ & $147.6 \pm 113.2$ & $54.5 \pm 33.6$ & $8.8 \pm 6.4$ & $158.4 \pm 35.9$ \\
Aldosterone post NaCl $(\mathrm{pg} / \mathrm{ml})$ & $217.3 \pm 156.5$ & $107.7 \pm 71.1$ & n.d. & \\
\hline
\end{tabular}

APA, aldosterone-producing adenoma; IHA, adrenal hyperplasia. 
Table 2 Primers and GenBank accession numbers of the real-time PCR assays.

\begin{tabular}{llll}
\hline Gene & GenBank accession number & Left primer & Right primer \\
\hline AGTR1 & NM_009585 & atttgtgaaagaaggagcaaga & tgctcatttggtagtgaagtgc \\
GIPR & NM_000164 & ccaagctcggcttgagat & gtagaggacgctgaccagga \\
MC2R & NM_000529 & cccagaaagttcctgcttca & tcttcaggatctttcttccttg \\
GNRHR & NM_000406 & cacgggtccttcatcagg & gcaaatgcaaccgtcatttt \\
LHCGR & NM_000233 & cattcaatgggacgacactg & gcctccaggagattgacaaa \\
TRHR & NM_003301 & gatgtttcaacagcacagtatcttc & acaaccactgccagcatctt \\
TSHR & NM_001018036 & ggacaaagctggatgctgtt & cttccaagaggtagcagcaag \\
GCGR & NM_000160 & ccagtgtcaccacaacctga & aggaatacttgtcgaaggttctgt \\
AVPR1A & NM_000706 & tttgtgatcgtgacggctta & tggtgatggtagggtttcc \\
AVPR2 & NM_000054 & cctccaggccctcagaac & ctcctggctgctgttgct \\
HTR4 & NM_199453 & atggccatcttggggaac & gatccgcaaaaagcaagagat \\
HPRT1 & NM_000194 & tgctgacctgctggattaca & cctgaccaaggaaagcaaag \\
\hline
\end{tabular}

expression of hPRT as a housekeeping gene and were expressed relative to the mean mRNA expression levels of six normal adrenals.

\section{Clinical study protocol}

The patients and controls participated in a 3-day test protocol, combining eight stimulation tests adapted from the studies by Lacroix et al. (6). Hypokalemia was corrected at least the day before study entry. On day 1, the subjects remained in a recumbent position from $0500 \mathrm{~h}$ until $0800 \mathrm{~h}$ when an i.v catheter was placed and two blood samples were collected. Afterwards, the subjects were advised to remain upright until $1215 \mathrm{~h}$. The remaining test protocol was performed in a sitting or standing upright position. A standard mixed meal was served at $1230 \mathrm{~h}$ and $250 \mu \mathrm{g}$ ACTH 1-24 (Synacthen, Novartis) were administered at $1430 \mathrm{~h}$. On day 2, $100 \mu \mathrm{g}$ GnRH (Relefact LHRH, AventisSanofi, Frankfurt, Germany) was injected at 0815 h, followed by $200 \mu \mathrm{g}$ TRH (Antepan, Henning, Berlin, Germany) at $1215 \mathrm{~h}$ and $1 \mathrm{mg}$ glucagon (GlucaGen, NovoNordisk, Mainz, Germany) at 1445 h. The tests on day 3 were performed after dexamethasone suppression (1 mg dexamethasone at $23 \mathrm{~h}$ on day 2 and $0.5 \mathrm{mg}$ at $0800 \mathrm{~h}$ on day 3). Ten units of L-arginine-vasopressin (Vasopressin Injection USP, American Regent, Shirley, NY, USA) were injected intramuscularly at $0800 \mathrm{~h}$ under close blood pressure monitoring. At $1030 \mathrm{~h}$, 10 mg metoclopramide (MCP; Paspertin, Solvay, Hanover, Germany) were given intravenously. Blood was drawn at least every $30 \mathrm{~min}$ with the exception of the posture test where blood samples were obtained at 0845, 1015, and $1215 \mathrm{~h}$. In order to control for physiologic aldosterone changes due to diurnal rhythms an aldosterone day profile without stimulation test was performed in the control subjects. An aldosterone increase of more than $50 \% 30$ or 60 min after stimulation was interpreted as a positive response. Because positive test results might be due to activation of the HPA axis or the renin-angiotensin system, ACTH and renin were measured for those time intervals where an aldosterone increase had been noted.

\section{Hormone assays}

EDTA blood was centrifuged and stored at $-20{ }^{\circ} \mathrm{C}$ until measurement. Aldosterone was measured using a commercial RIA (Coat-a-Count Aldosterone, DPCBiermann, Bad Nauheim, Germany), using a Wallac 1470 Wizard gamma-counter (Perkin-Elmer, Wellesley, MA, USA). ACTH was determined by chemiluminescence (Immulite 2000 ACTH, DPC Biermann, Bad Nauheim, Germany). For renin measurement, an IRMA (Renin III Generation IRMA, CISbio International, Gif-sur-Yvette Cedex, France) was used.

\section{Statistical analysis}

All clinical data were analyzed using Excel (Microsoft) and StatView (SAS Institute, Cary, NC, USA). Significance was determined with a Mann-Whitney $U$ test and was assumed for $P<0.05$.

\section{Results}

\section{Quantitative PCR}

The results of the quantitative PCR are summarized in Table 3. Efficiency of all qPCR assays was between 98 and $120 \%\left(R^{2}>0.98\right)$. Positive receptor mRNA expression was assumed for a threshold cycle (ct) below 35 with a plateau after amplification, a single peak in the melting curve without primer dimers and a single specific band on an agarose gel. As expected, AT2R1, MC2R, and 5-HT4R mRNA were abundantly expressed in normal adrenals and tumorous tissues. Furthermore, V1aR and V2R mRNA were detected in all tissues with varying amounts as described previously (17). LHR mRNA levels were found in all normal adrenals. Of the 15 adenomas, 13 had comparable expression levels, whereas one adenoma showed moderately elevated mRNA expression. Four of the 15 samples exhibited positive GnRHR and one additional tumor TSHR mRNA expression. None of the tissues showed expression of GIPR, TRHR or GCGR. 
Table 3 Results of the quantitative real-time PCR

\begin{tabular}{|c|c|c|c|c|c|c|c|c|c|c|c|}
\hline & AT2R1 & GIPR & MC2R & GnRHR & LHR & TRHR & TSHR & Glucagon-R & V1aR & V2R & 5-HT4R \\
\hline $\begin{array}{l}\text { Normal } \\
\text { adrenal }\end{array}$ & 100 & n.d. & 100 & n.d. & 100 & n.d. & n.d. & n.d. & 100 & 100 & 100 \\
\hline Tu 1 & 201 & n.d. & 714 & n.d. & 41 & n.d. & n.d. & n.d. & 30 & 39 & 1949 \\
\hline Tu $2^{\mathrm{a}, \mathrm{b}}$ & 367 & n.d. & 2064 & 32961 & 165 & n.d. & n.d. & n.d. & 29 & 52 & 11835 \\
\hline Tu $3^{\mathrm{a}}$ & 88 & n.d. & 201 & n.d. & 62 & n.d. & n.d. & n.d. & 203 & 156 & 139 \\
\hline Tu 4 & 139 & n.d. & 374 & n.d. & 6 & n.d. & n.d. & n.d. & 11 & 20 & 2013 \\
\hline Tu 5 & 185 & n.d. & 198 & n.d. & 23 & n.d. & 12389 & n.d. & 16 & 30 & 2038 \\
\hline Tu $6^{a}$ & 133 & n.d. & 179 & 1836 & 143 & n.d. & n.d. & n.d. & 92 & 152 & 983 \\
\hline Tu 7 & 238 & n.d. & 589 & n.d. & 790 & n.d. & n.d. & n.d. & 1 & 3 & 5737 \\
\hline Tu 8 & 629 & n.d. & 739 & 9456 & 52 & n.d. & n.d. & n.d. & 33 & 53 & 5206 \\
\hline Tu 9 & 62 & n.d. & 31 & n.d. & 14 & n.d. & n.d. & n.d. & 77 & 155 & 140 \\
\hline Tu 10 & 66 & n.d. & 77 & n.d. & 10 & n.d. & n.d. & n.d. & 42 & 40 & 100 \\
\hline Tu 11 & 88 & n.d. & 42 & n.d. & 44 & n.d. & n.d. & n.d. & 47 & 122 & 54 \\
\hline Tu 12 & 133 & n.d. & 80 & n.d. & 9 & n.d. & n.d. & n.d. & 10 & 18 & 237 \\
\hline Tu 13 & 137 & n.d. & 104 & n.d. & 11 & n.d. & n.d. & n.d. & 54 & 36 & 219 \\
\hline Tu 14 & 168 & n.d. & 374 & 1242 & 12 & n.d. & n.d. & n.d. & 24 & 35 & 1629 \\
\hline Tu 15 & 178 & n.d. & 138 & n.d. & n.d. & n.d. & n.d. & n.d. & 8 & 13 & 2669 \\
\hline $\begin{array}{l}\text { Overall } \\
\text { positive test } \\
\text { result (\%) }\end{array}$ & $\begin{array}{l}15 / 15 \\
\quad(100 \%)\end{array}$ & $\begin{array}{l}0 / 15 \\
\quad(0 \%)\end{array}$ & $\begin{array}{l}15 / 15 \\
(100 \%)\end{array}$ & $\begin{array}{l}4 / 15 \\
\quad(27 \%)\end{array}$ & $\begin{array}{c}14 / 15 \\
(93 \%)\end{array}$ & $\begin{array}{l}0 / 15 \\
\quad(0 \%)\end{array}$ & $\begin{array}{l}1 / 15 \\
(7 \%)\end{array}$ & $\begin{array}{l}0 / 15 \\
(0 \%)\end{array}$ & $\begin{array}{l}15 / 15 \\
(100 \%)\end{array}$ & $\begin{array}{l}15 / 15 \\
(100 \%)\end{array}$ & $\begin{array}{l}15 / 15 \\
\quad(100 \%)\end{array}$ \\
\hline
\end{tabular}

Values are normalized for hPRT as a housekeeping gene and expressed in percent of the mean of six healthy adult adrenal glands. n.d., not detectable.

${ }^{\text {ap }}$ atients included into both parts of the study.

${ }^{\mathrm{b}}$ Tumor 2 was histologically denoted as adrenal hyperplasia in spite of unilateral aldosterone excess.

\section{Stimulation tests}

The time course of the mean aldosterone levels ( \pm s.e.m.) for APA, IHA, and control subjects on the three test days is given in Fig. 1. Overall, APA patients (baseline aldosterone levels $432 \pm 113 \mathrm{pg} / \mathrm{ml}$, mean \pm s.e.m.) had significantly higher aldosterone levels compared with IHA $(102 \pm 17 \mathrm{pg} / \mathrm{ml})$ and controls $(58 \pm 16 \mathrm{pg} / \mathrm{ml}$, $P<0.05$ and $P<0.006$ respectively). Dexamethasone suppression on day 3 resulted in significantly lower aldosterone levels in APA patients (from $554 \pm$ $164 \mathrm{pg} / \mathrm{ml}$ to $236 \pm 65 \mathrm{pg} / \mathrm{ml}, P<0.02$ ) in comparison with baseline values from day 2 , while no suppression was detectable in controls $(118 \pm 18 \mathrm{pg} / \mathrm{ml}$ and $199 \pm$ $35 \mathrm{pg} / \mathrm{ml}, P<0.3)$. Patients with IHA displayed inconsistent responses upon dexamethasone suppression with increasing or decreasing aldosterone values (decrease from $139 \pm 43 \mathrm{pg} / \mathrm{ml}$ to $99 \pm 21 \mathrm{pg} / \mathrm{ml}, P<0.9$ ). The results of the individual stimulation tests are given in detail in Table 4 and a summary is shown in Fig. 2.

During posture, one out of five patients with APA, four out of seven patients with IHA and three out of eight normal subjects showed an increase of aldosterone levels of more than 50\% over baseline after $2 \mathrm{~h}$ (Table 4). In all but one patient renin levels were suppressed, even after posture changes. In the remaining APA patient, a moderate rise in renin from 11 to $28 \mathrm{mU} / \mathrm{l}$ was not accompanied by a relevant aldosterone increase. By contrast, six out of the eight control subjects showed a renin increase $30 \mathrm{~min}$ after posture, resulting in a positive aldosterone response $>50 \%$ in three control subjects. None of the patients had a positive response to a mixed-meal test, excluding clinically relevant adrenal GIP-R expression in our cohort of patients. As expected, almost all patients $(11 / 12)$ and all control subjects had an aldosterone increase following ACTH stimulation, with one IHA patient not reaching $50 \%$ increase from a high baseline level. One patient with APA and two patients with IHA responded to GnRH stimulation, compared with 0 out of eight controls. One patient with IHA showed a positive response following TRH, compared with 0 out of five APA and 0 out of eight controls. The administration of glucagon resulted in an aldosterone increase $>50 \%$ in one patient with APA, one patient with IHA and one control subject. Two out of 5 patients with APA and four out of seven patients with IHA had an aldosterone response following AVP, compared with three out of eight control subjects. In accordance with our expression analysis demonstrating 5-HT4R expression in all cases studied, four out of five patients with APA and all patients with IHA had a positive response following MCP, as compared with three out of eight controls. A summary of the results of the stimulation test is shown in Fig. 2.

To exclude HPA axis stimulation during the test protocol as a relevant cause of aldosterone secretion, ACTH levels were determined at all time points with positive aldosterone response. However, none of the aldosterone responses was preceded or accompanied by a significant increase of ACTH. Dexamethasone treatment on day 3 resulted in readily suppressed ACTH levels (data not shown). Similarly, renin levels remained suppressed in all patients with PA during baseline and specific stimulation tests. Furthermore, no stimulation of renin from baseline values within the lower normal range was seen in the control subjects, excluding a role of renin for the positive responses following AVP and MCP. 


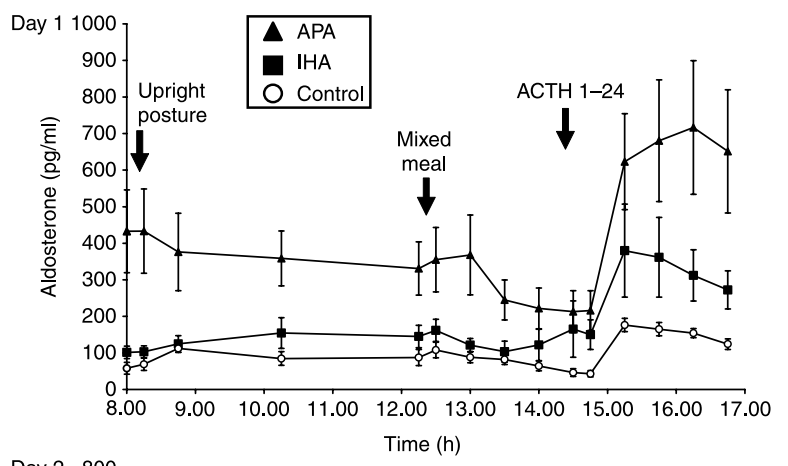

mRNA expression in the tissues, while APA patient five had a diagnostic aldosterone decrease instead of being positive for a AT2R1 mRNA (Table 5). All patients responded to ACTH and MCP and had the corresponding receptor expressed. Negative results correlated for mixed meal, TRH, and glucagon stimulation with the lack of GIP-R, TRH/TSH-R, and GCGR expression respectively. Interestingly, one of the patients with positive response to GnRH had very high GnRHR mRNA levels. Another patient with a moderate GnRH response showed also moderate LHR mRNA and the third patient with negative response displayed only very low LHR mRNA expression. The vasopressin response correlated with V1aR and V2R mRNA expression in two patients, while in the remaining, a non-sufficient aldosterone increase of $45 \%$ was accompanied by positive receptor expression. Taken together, in the majority of cases, detection of specific peptide receptor expression predicted positive aldosterone response upon defined stimulation testing (Table 5).

\section{Discussion}
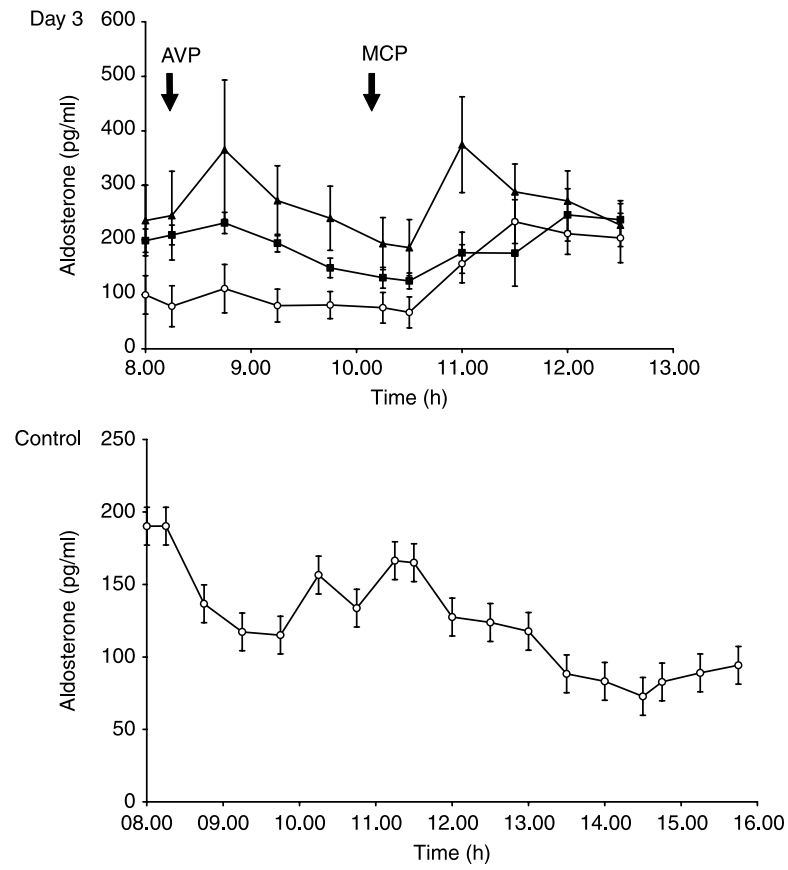

Figure 1 Mean aldosterone levels of APA (black triangles), IHA (black squares), and control subjects (white circles) during the three test days in $\mathrm{pg} / \mathrm{ml}$ ( \pm S.E.M). The administration of the test substances is indicated with arrows. Control: mean aldosterone levels of the control subjects without stimulation.

\section{Comparison of clinical and molecular results}

Two patients with APA and one with unilateral IHA were included into both parts of the study. In the posture test, one APA and IHA patient showed an aldosterone increase corresponding to the presence of AT2R1

Although APA and IHA are the two most common causes for PA, little is known about the molecular pathogenesis that results in autonomous overproduction of aldosterone in these entities. In adrenal Cushing's syndrome, illicit peptide hormone receptor expression has been demonstrated as the basis for the excessive glucocorticoid secretion in a subset of patients. Similarly, in PA, some studies suggested expression of ectopic or malfunction of eutopic receptors in a subset of patients as the potential cause for autonomous aldosterone production (23). However, the molecular detection of receptor expression does not necessarily implicate its role in hormone overproduction. Therefore, we applied a quantitative PCR approach and a clinical screening test protocol, adapted from Lacroix et al. (6), to systematically evaluate the potential role of peptide hormone receptors in PA. Our data provide evidence for a variety of peptide hormone receptors expressed in adrenal tissues with subsequent peptide hormone responsiveness also in the absence of adrenal disease. By contrast, responses to specific stimuli including GnRH and TRH seem to be unique in magnitude to PA as a similar response was not seen in the included normal controls.

As a positive control, we applied the ACTH stimulation test as earlier experiments have indicated high levels of ACTH receptor expression in normal glomerulosa cells as well as in APAs and IHA $(28,29)$. In accordance with these results, we could demonstrate high MC2R mRNA expression levels and ACTH responsiveness of aldosterone secretion in all cases studied. Similarly and as expected from its physiological role in aldosterone regulation, all tissue samples showed AT2R1 mRNA expression. Basis for the role of the 
Table 4 Results of the stimulation tests.

\begin{tabular}{|c|c|c|c|c|c|c|c|c|c|}
\hline $\begin{array}{l}\text { Patient } \\
\text { numbers }\end{array}$ & Diagnosis & $\begin{array}{l}\text { Posture } \\
(2 \mathrm{~h})\end{array}$ & Mixed meal & АСТН & GnRH & TRH & Glucagon & AVP & MCP \\
\hline P 1 & APA & -21 & -47 & 299 & -35 & 12 & 65 & 56 & 95 \\
\hline $\mathrm{P} 2$ & APA & -16 & 42 & 408 & -7 & -57 & 17 & 42 & 48 \\
\hline P 3 & APA & -27 & -24 & 124 & -50 & 14 & -15 & 34 & 165 \\
\hline$P 4^{a}$ & APA & 146 & 8 & 142 & 57 & 2 & 8 & 96 & 114 \\
\hline$P 5^{\mathrm{a}}$ & APA & -39 & 12 & 132 & 16 & 5 & 14 & 45 & 174 \\
\hline P 6 & $\mathrm{IHA}$ & 192 & -20 & 173 & -40 & -24 & -55 & -58 & 189 \\
\hline P 7 & $\mathrm{IHA}$ & 105 & -70 & 41 & 66 & 423 & 6 & 79 & 410 \\
\hline P 8 & $\mathrm{IHA}$ & 23 & 35 & 129 & -38 & -66 & 240 & 103 & 108 \\
\hline P 9 & $\mathrm{IHA}$ & -16 & -44 & 279 & -35 & -12 & 2 & -20 & 99 \\
\hline$P 10^{a}$ & Unilateral IHA & 58 & -40 & 230 & 128 & -52 & 8 & 149 & 359 \\
\hline P 11 & IHA & 16 & -53 & 76 & 41 & -17 & -47 & 172 & 125 \\
\hline P 12 & $\mathrm{IHA}$ & -25 & -14 & 130 & -55 & -15 & 30 & 9 & 380 \\
\hline C 1 & Control & 94 & -42 & 115 & -41 & -36 & -51 & -43 & 23 \\
\hline C 2 & Control & -69 & 50 & 357 & -26 & 35 & 64 & 58 & 247 \\
\hline C 3 & Control & -12 & -17 & 788 & -58 & -61 & -33 & -37 & 39 \\
\hline C 4 & Control & 134 & -42 & 610 & -10 & 22.5 & -32 & -44 & 71 \\
\hline C 5 & Control & 180 & 40 & 520 & -47 & -49 & -64 & 16 & 41 \\
\hline C 6 & Control & 7 & -46 & 237 & -39 & 4 & -13 & -2 & 22 \\
\hline C 7 & Control & 12 & -46 & 496 & -33 & 27 & 4 & 112 & 203 \\
\hline C 8 & Control & 25 & -20 & 72 & -52 & -64 & -65 & 77 & -19 \\
\hline
\end{tabular}

The percentage of maximum aldosterone increase over baseline (=100\%) after 30 or 60 min is shown. APA, aldosterone-producing adenoma; IHA, adrenal hyperplasia. Responses $>50 \%$ are shown in bold.

apatients included into both parts of the study.

posture test in the differential diagnosis of PA is the predominant dependence of aldosterone response to ACTH in APA and to ATII in IHA although the specificity of the test is compromised by commonly observed ATII responsiveness of Conn adenomas (30). Accordingly, four out of five APA in our study displayed decreasing aldosterone levels following posture. By contrast, five out of the seven patients with IHA showed the expected aldosterone increase, with three patients having a positive aldosterone response with respect to the predefined test criteria while two patients showed a decline in aldosterone during the posture test. As all tissues studied by PCR displayed robust expression of both MC2R and AT2R1 mRNA, measurement of expression levels of these receptors is unlikely to predict posture test results. Moreover, active renin concentration in our patients suggested suppressed renin angiotensin system without an increase of renin concentrations following posture even in patients with positive aldosterone response. By contrast, six out of eight controls displayed an increase in renin activity upon posture that was accompanied by an aldosterone increase in three out of eight after $2 \mathrm{~h}$. Thus, the molecular basis of the individual aldosterone response following the posture test is complex and might well involve other signaling pathways i.e. beta-adrenergic stimulation.

5-HT4 receptors are present in the normal adrenal cortex (26) and in the adrenals of patients with AIMAH (20). Accordingly, a strong stimulating effect of serotonergic substances have been described for aldosterone secretion and to a weaker degree for cortisol secretion $(31,32)$. Furthermore, in vitro and in vivo studies have demonstrated the presence of 5-HT4 receptors in APA (23, 27). In accordance with these results, we confirmed a strong 5-HT4R mRNA expression by quantitative PCR and a positive response to metoclopamide in all APA and IHA patients as well as in roughly half of the control subjects, providing indirect evidence for a high frequency of 5-HT4R expression in adrenal tissues. Independent of autonomous aldosterone secretion, these mechanisms might modulate blood pressure and fluid homeostasis regulation.

The effects of vasopressin on cortisol (33) and short term aldosterone release are well established (34) and $\mathrm{V} 1 \mathrm{aR}$ are present in normal adrenal tissue, in

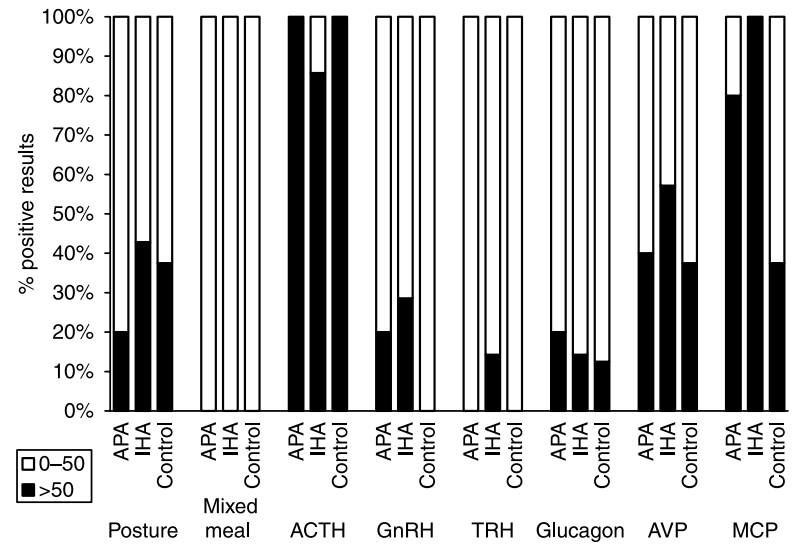

Figure 2 Assumed receptor expression following the results of the clinical test protocol in the three study groups with adrenal adenoma (APA), adrenal hyperplasia (IHA), and control subjects. The percentages of subjects responding with an aldosterone increase over baseline of more than $50 \%$ are shown. 


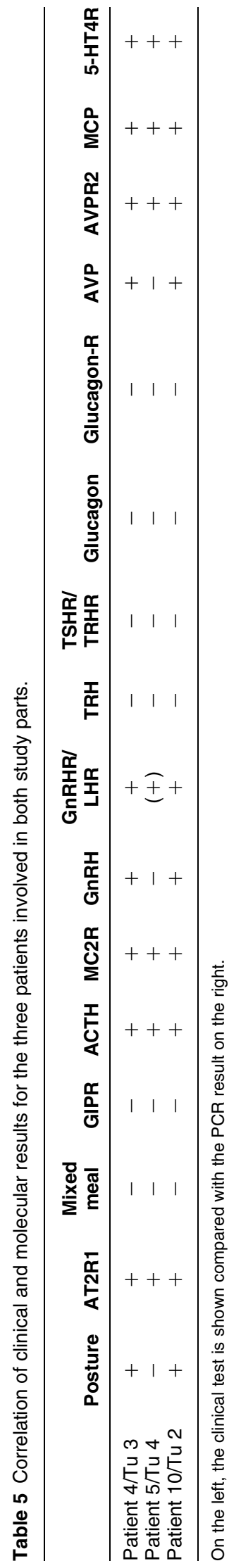

cortisol-producing adrenal adenomas, AIMAH as well as in aldosteronomas $(19,24,35)$. In addition, AVP stimulates central ACTH secretion (36), which in turn can modulate aldosterone release. Moreover, vasopressin secretion by chromaffin cells has been suggested to influence aldosterone synthesis in a paracrine manner (37). Vasopressin plays a role in fluid homeostasis and is activated following posture changes. Therefore, an interdependence of vasopressin and aldosterone in fluid and salt homeostasis is likely to occur. In accordance with these results, V1aR and V2R mRNA were detectable in all tumors and a positive aldosterone response could be observed in two out of five patients with APA, with the remaining three patients not reaching $50 \%$ due to high baseline levels. In addition, three out of seven patients with IHA and three out of eight control patients had a positive response. ACTHmediated aldosterone stimulation by AVP was excluded by dexamethasone suppression with ACTH levels being suppressed throughout the stimulation. Taken together, vasopressin is likely to play an important role in modulating aldosterone response under physiologic and pathophysiologic conditions also through ACTHindependent mechanisms.

One patient with IHA displayed a strong aldosterone increase following TRH stimulation. Interestingly, TSH has been found to stimulate cAMP production in vitro in rat and human adrenocortical primary cancer cells (38, 39). Furthermore, TSHR mRNA has been demonstrated in normal adrenal tissue (40). In vivo, no TRH or TSHdependent adrenal stimulation has been reported to date. Unfortunately, we were not able to investigate the tissue of the patient for TRHR or TSHR expression. However, during our expression profiling study, we found one additional APA tissue to be positive for TSHR. These results warrant further investigation as they imply potential aldosterone responsiveness to TRH or TSH in a subset of patients.

Three patients responded to GnRH, suggesting the expression of LH or GnRH receptors. LH receptors are expressed in normal adrenal tissue in low amounts, as could be confirmed by our quantitative PCR. Recently, Saner-Amigh et al. investigated 18 APA for LH receptor expression using microarray experiments. They found one tumor with a 2400-fold mRNA overexpression of the receptor and eight other tumors with moderately elevated LH-R levels compared with normal adrenal samples. Furthermore, they demonstrated that overexpression of LH receptor mRNA in NCI H295 cells stimulated CYP11B2 expression, substantiating the involvement of LH receptor-dependent pathways as a potential cause of aldosterone excess at least in individual patients (22). Extending on their findings, the same group showed GnRHR expression in 11 out of 28 APA but only 1 out of 13 cortisol-producing adenomas (23). These results are supported by our quantitative PCR showing GnRHR expression in 4 out of 15 tissues, including one patient with clinical response 
displaying a 329-fold GnRHR mRNA overexpression. LHR mRNA was expressed in low amounts in 14 out of the 15 tissues with elevated expression compared with normal adrenal tissue in only one case. Taken together, these results support the concept of LH- or GnRHdependent aldosterone secretion in a subset of patients with APA and IHA.

All patients included in the clinical part of the study had severe hypertension. The study protocol was performed after discontinuation of spironolactone and $\beta$-blockers in the course of routine diagnostics for PA. After this diagnostic workup, medical therapy with spironolactone or surgical adrenalectomy was performed as soon as possible. Therefore, further testing for confirmation and characterization of the receptors was impossible.

In summary, aldosterone secretion seems to be susceptible to stimuli by various peptide hormones as suggested by clinical and molecular testing. For our limited number of cases, a close correlation of both test results could be observed, making a relevant influence of the stimuli possible. In particular, the role of GnRHR and TSHR has to be further substantiated, as these could be detected exclusively in adrenal tumors, but not in control subjects.

\section{Declaration of interest}

The authors declare that there is no conflict of interest that could be perceived as prejudicing the impartiality of the research reported.

\section{Funding}

This work was supported by a grant from the Friedrich-Baur-Stiftung. This work is part of the thesis of Yana Suttmann at the LudwigMaximilians-University Munich, Germany.

\section{Acknowledgements}

We would like to thank Brigitte Mauracher, Sarina Meurer, Juliane Ramisch, and Rita Schwaiger for their excellent technical assistance and Kathy Muller-Schertler for language editing of the manuscript.

\section{References}

1 Mulatero P, Stowasser M, Loh KC, Fardella CE, Gordon RD, Mosso L, Gomez-Sanchez CE, Veglio F \& Young WF Jr. Increased diagnosis of primary aldosteronism, including surgically correctable forms, in centers from five continents. Journal of Clinical Endocrinology and Metabolism 200489 1045-1050.

2 Rossi GP, Bernini G, Caliumi C, Desideri G, Fabris B, Ferri C, Ganzaroli C, Giacchetti G, Letizia C, Maccario M, Mallamaci F, Mannelli M, Mattarello MJ, Moretti A, Palumbo G, Parenti G, Porteri E, Semplicini A, Rizzoni D, Rossi E, Boscaro M, Pessina AC \& Mantero F. A prospective study of the prevalence of primary aldosteronism in 1,125 hypertensive patients. Journal of the American College of Cardiology 200648 2293-2300.

3 Conn JW. Primary aldosteronism. Journal of Laboratory and Clinical Medicine 195545 661-664.

4 Reznik Y, Allali-Zerah V, Chayvialle JA, Leroyer R, Leymarie P, Travert G, Lebrethon MC, Budi I, Balliere AM \& Mahoudeau J.
Food-dependent Cushing's syndrome mediated by aberrant adrenal sensitivity to gastric inhibitory polypeptide. New England Journal of Medicine 1992327 981-986.

5 Lacroix A, Bolte E, Tremblay J, Dupre J, Poitras P, Fournier H, Garon J, Garrel D, Bayard F, Taillefer R et al. Gastric inhibitory polypeptide-dependent cortisol hypersecretion - a new cause of Cushing's syndrome. New England Journal of Medicine 1992327 974-980.

6 Lacroix A, Ndiaye N, Tremblay J \& Hamet P. Ectopic and abnormal hormone receptors in adrenal Cushing's syndrome. Endocrine Reviews 200122 75-110.

7 Mircescu H, Jilwan J, N'Diaye N, Bourdeau I, Tremblay J, Hamet P \& Lacroix A. Are ectopic or abnormal membrane hormone receptors frequently present in adrenal Cushing's syndrome? Journal of Clinical Endocrinology and Metabolism 200085 $3531-3536$.

8 Bertherat J, Contesse V, Louiset E, Barrande G, Duparc C, Groussin L, Emy P, Bertagna X, Kuhn JM, Vaudry H \& Lefebvre $\mathrm{H}$. In vivo and in vitro screening for illegitimate receptors in adrenocorticotropin-independent macronodular adrenal hyperplasia causing Cushing's syndrome: identification of two cases of gonadotropin/gastric inhibitory polypeptide-dependent hypercortisolism. Journal of Clinical Endocrinology and Metabolism 200590 1302-1310.

9 Reznik Y, Lefebvre H, Rohmer V, Charbonnel B, Tabarin A, Rodien P, Lecomte P, Bardet S, Coffin C \& Mahoudeau J. Aberrant adrenal sensitivity to multiple ligands in unilateral incidentaloma with subclinical autonomous cortisol hypersecretion: a prospective clinical study. Clinical Endocrinology 200461 311-319.

10 Christopoulos S, Bourdeau I \& Lacroix A. Clinical and subclinical ACTH-independent macronodular adrenal hyperplasia and aberrant hormone receptors. Hormone Research 200564 119-131.

11 Lacroix A, Hamet P \& Boutin JM. Leuprolide acetate therapy in luteinizing hormone - dependent Cushing's syndrome. New England Journal of Medicine 1999341 1577-1581.

12 Bourdeau I, D'Amour P. Hamet P, Boutin JM \& Lacroix A. Aberrant membrane hormone receptors in incidentally discovered bilateral macronodular adrenal hyperplasia with subclinical Cushing's syndrome. Journal of Clinical Endocrinology and Metabolism 2001 86 5534-5540.

13 Feelders RA, Lamberts SW, Hofland LJ, van Koetsveld PM, VerhoefPost M, Themmen AP, de Jong FH, Bonjer HJ, Clark AJ, van der Lely AJ \& de Herder WW. Luteinizing hormone (LH)-responsive Cushing's syndrome: the demonstration of LH receptor messenger ribonucleic acid in hyperplastic adrenal cells, which respond to chorionic gonadotropin and serotonin agonists in vitro. Journal of Clinical Endocrinology and Metabolism 200388 230-237.

14 Lacroix A, Tremblay J, Rousseau G, Bouvier M \& Hamet P. Propranolol therapy for ectopic beta-adrenergic receptors in adrenal Cushing's syndrome. New England Journal of Medicine 1997337 1429-1434.

15 Willenberg HS, Stratakis CA, Marx C, Ehrhart-Bornstein M, Chrousos GP \& Bornstein SR. Aberrant interleukin-1 receptors in a cortisol-secreting adrenal adenoma causing Cushing's syndrome. New England Journal of Medicine 1998339 27-31.

16 Nakamura Y, Son Y, Kohno Y, Shimono D, Kuwamura N, Koshiyama H, Sasano H \& Matsuda T. Case of adrenocorticotropic hormone-independent macronodular adrenal hyperplasia with possible adrenal hypersensitivity to angiotensin II. Endocrine 2001 15 57-61.

17 Arnaldi G, Gasc JM, de Keyzer Y, Raffin-Sanson ML, Perraudin V, Kuhn JM, Raux-Demay MC, Luton JP, Clauser E \& Bertagna X. Variable expression of the V1 vasopressin receptor modulates the phenotypic response of steroid-secreting adrenocortical tumors. Journal of Clinical Endocrinology and Metabolism $1998 \mathbf{8 3}$ 2029-2035.

18 Daidoh H, Morita H, Hanafusa J, Mune T, Murase H, Sato M, Shibata T, Suwa T, Ishizuka T \& Yasuda K. In vivo and in vitro effects of AVP and V1a receptor antagonist on Cushing's syndrome due to ACTH-independent bilateral macronodular adrenocortical hyperplasia. Clinical Endocrinology 199849 403-409. 
19 Louiset E, Contesse V, Groussin L, Cartier D, Duparc C, Perraudin V, Bertherat J \& Lefebvre H. Expression of vasopressin receptors in ACTH-independent macronodular bilateral adrenal hyperplasia causing Cushing's syndrome: molecular, immunohistochemical and pharmacological correlates. Journal of Endocrinology 2008 $1961-9$.

20 Cartier D, Lihrmann I, Parmentier F, Bastard C, Bertherat J, Caron P, Kuhn JM, Lacroix A, Tabarin A, Young J, Vaudry H \& Lefebvre H. Overexpression of serotonin 4 receptors in cisaprideresponsive adrenocorticotropin-independent bilateral macronodular adrenal hyperplasia causing Cushing's syndrome. Journal of Clinical Endocrinology and Metabolism 200388 248-254.

21 Mannelli M, Ferruzzi P, Luciani P, Crescioli C, Buci L, Corona G, Serio M \& Peri A. Cushing's syndrome in a patient with bilateral macronodular adrenal hyperplasia responding to cisapride: an in vivo and in vitro study. Journal of Clinical Endocrinology and Metabolism $2003 \mathbf{8 8}$ 4616-4622.

22 Saner-Amigh K, Mayhew BA, Mantero F, Schiavi F, White PC, Rao CV \& Rainey WE. Elevated expression of luteinizing hormone receptor in aldosterone-producing adenomas. Journal of Clinical Endocrinology and Metabolism 200691 1136-1142.

23 Ye P, Mariniello B, Mantero F, Shibata H \& Rainey WE. G-proteincoupled receptors in aldosterone-producing adenomas: a potential cause of hyperaldosteronism. Journal of Endocrinology 2007195 39-48.

24 Perraudin V, Delarue C, Lefebvre H, Do Rego JL, Vaudry H \& Kuhn JM. Evidence for a role of vasopressin in the control of aldosterone secretion in primary aldosteronism: in vitro and in vivo studies. Journal of Clinical Endocrinology and Metabolism 200691 1566-1572.

25 Cartier D, Jegou S, Parmentier F, Lihrmann I, Louiset E, Kuhn JM, Bastard C, Plouin PF, Godin M, Vaudry H \& Lefebvre H. Expression profile of serotonin4 (5-HT4) receptors in adrenocortical aldosterone-producing adenomas. European Journal of Endocrinology 2005153 939-947.

26 Lefebvre H, Gonzalez KN, Contesse V, Delarue C, Vaudry H \& Kuhnl JM. Effect of prolonged administration of the serotonin4 (5-HT4) receptor agonist cisapride on aldosterone secretion in healthy volunteers. Endocrine Research 199824 749-752.

27 Lefebvre H, Cartier D, Duparc C, Lihrmann I, Contesse V, Delarue C, Godin M, Fischmeister R, Vaudry H \& Kuhn JM. Characterization of serotonin(4) receptors in adrenocortical aldosterone-producing adenomas: in vivo and in vitro studies. Journal of Clinical Endocrinology and Metabolism $2002 \mathbf{8 7}$ 1211-1216.

28 Reincke M, Beuschlein F, Menig G, Hofmockel G, Arlt W, Lehmann R, Karl M \& Allolio B. Localization and expression of adrenocorticotropic hormone receptor mRNA in normal and neoplastic human adrenal cortex. Journal of Endocrinology 1998 $156415-423$.
29 Schubert B, Fassnacht M, Beuschlein F, Zenkert S, Allolio B \& Reincke M. Angiotensin II type 1 receptor and ACTH receptor expression in human adrenocortical neoplasms. Clinical Endocrinology $200154627-632$.

30 Nomura K, Toraya S, Horiba N, Ujihara M, Aiba M \& Demura H. Plasma aldosterone response to upright posture and angiotensin II infusion in aldosterone-producing adenoma. Journal of Clinical Endocrinology and Metabolism 199275 323-327.

31 Ganguly A, Pratt JH, Weinberger MH, Grim CE \& Fineberg NS. Differing effects of metoclopramide and adrenocorticotropin on plasma aldosterone levels in glucocorticoid-suppressible hyperaldosteronism and other forms of hyperaldosteronism. Journal of Clinical Endocrinology and Metabolism 198357 388-392.

32 Lefebvre H, Contesse V, Delarue C, Vaudry H \& Kuhn JM. Serotonergic regulation of adrenocortical function. Hormone and Metabolic Research $199830398-403$.

33 Perraudin V, Delarue C, Lefebvre H, Contesse V, Kuhn JM \& Vaudry H. Vasopressin stimulates cortisol secretion from human adrenocortical tissue through activation of $\mathrm{V} 1$ receptors. Journal of Clinical Endocrinology and Metabolism $1993761522-1528$.

34 Guillon G, Trueba M, Joubert D, Grazzini E, Chouinard L, Cote M, Payet MD, Manzoni O, Barberis C, Robert M \& Gallo-Payet N. Vasopressin stimulates steroid secretion in human adrenal glands: comparison with angiotensin-II effect. Endocrinology 1995136 $1285-1295$.

35 Mune T, Murase H, Yamakita N, Fukuda T, Murayama M, Miura A, Suwa T, Hanafusa J, Daido H, Morita H \& Yasuda K. Eutopic overexpression of vasopressin vla receptor in adrenocorticotropin-independent macronodular adrenal hyperplasia. Journal of Clinical Endocrinology and Metabolism $2002 \quad 87$ 5706-5713.

36 Coslovsky R, Wajchenberg BL \& Nogueira O. Hyperresponsiveness to lysine-vasopressin in Cushing's disease. Acta Endocrinologica 197475 125-132.

37 Gallo-Payet N \& Guillon G. Regulation of adrenocortical function by vasopressin. Hormone and Metabolic Research 199830 360-367.

38 Schorr I \& Ney RL. Abnormal hormone responses of an adrenocortical cancer adenyl cyclase. Journal of Clinical Investigation 197150 1295-1300.

39 Matsukura S, Kakita T, Sueoka S, Yoshimi H, Hirata Y, Yokota M \& Fujita T. Multiple hormone receptors in the adenylate cyclase of human adrenocortical tumors. Cancer Research $1980 \mathbf{4 0}$ 3768-3771.

40 Dutton CM, Joba W, Spitzweg C, Heufelder AE \& Bahn RS. Thyrotropin receptor expression in adrenal, kidney, and thymus. Thyroid 19977 879-884.

Received 31 December 2008

Accepted 3 January 2009 